\title{
A NEW GENUS AND TWO NEW SPECIES OF NEOPYGMEPHORIDAE (ACARI: PYGMEPHOROIDEA) PHORETIC ON SCARAB BEETLES
}

\author{
Alexander A. Khaustov ${ }^{* *}$ and Andrey V. Frolov ${ }^{2}$ \\ ${ }^{1} \mathrm{X}-\mathrm{BIO}$ Institute, Tyumen State University, Tyumen, Russia \\ ${ }^{2}$ Zoological Institute of the Russian Academy of Sciences, Saint Petersburg, Russia \\ *corresponding author; e-mail: alkhaustov@mail.ru
}

ABSTRACT: A new genus of Neopygmephorid mites (Acari: Neopygmephoridae), Andrebochkovia gen. n., and two new speciesA. cochlearis sp. n., collected from the beetle Apogonia destructor Bos (Scarabaeidae: Melolontinae) in Indonesia; and A. madagascariensis sp. n., collected from the beetle Adoretus cf. vittatus Brenske (Scarabaeidae: Rutelinae) in Madagascar-are described.

KEY WORDS: Heterostigmata, systematics, new taxa, phoresy, Indonesia, Madagascar.

DOI: 10.21684/0132-8077-2019-27-2-209-220

\section{INTRODUCTION}

The cosmopolitan family Neopygmephoridae includes 26 genera and about 300 species (Zhang et al. 2011; Khaustov and Sazhnev 2016; Khaustov and Mandelshtam 2017; Khaustov and Frolov 2018a, b; Khaustov and Minor 2018; Khaustov and OConnor 2019). All neopygmephorid mites are probably fungivorous. Representatives of five genera are known as associates of scarab beetles: Nasutidania Khaustov and Frolov, 2018; Pseudokerdabania Khaustov and Trach, 2012; Pseudopygmephorus Cross, 1965; Scarabadania Khaustov and Frolov, 2018; and Troxodania Khaustov and Trach 2014 (Khaustov 2010; Khaustov and Trach 2012, 2014; Sobhi et al. 2017: Khaustov and Frolov 2018a, b).

During the study of heterostigmatic mites phoretic on scarab beetles, a new genus of Neopygmephorid mites, Andrebochkovia gen. n., and two new species-A. cochlearis sp.n., collected from the beetle Apogonia destructor Bos in Indonesia; and A. madagascariensis sp.n., collected from the beetle Adoretus cf. vittatus Brenske in Madagascar-have been found. They are described herein.

\section{MATERIALS AND METHODS}

Although the collecting circumstances of the host beetles, which are housed in the collection of Zoological Institute of RAS, Saint Petersburg, Russia, were not recorded, we think they were collected in light traps. The exact collecting localities are provided below. The mites were found attached to the setae on the dorsal sides of the head and on the pronotums of the beetles. Collected mites were preserved in $70-80 \%$ ethanol and later cleared in lactic acid and mounted in Hoyer's medium. Mite morphology was studied using a Carl Zeiss AxioImager A2 compound microscope equipped with phase contrast and DIC objectives. Photomicrographs were taken with a Hitachi KP-HD20A digital camera. For SEM microscopy, alcoholpreserved mites were dried in a freeze-drying device JFD 320 (JEOL, Japan), dusted with gold, and scanned with the aid of a JEOL JSM-6510LV SEM microscope.

The terminology of the idiosoma and legs follows Lindquist (1986); the nomenclature of subcapitular setae and the designation of cheliceral setae follow Grandjean $(1944,1947)$, respectively. The taxonomic system of Pygmephoroidea follows Khaustov $(2004,2008)$. All measurements for the holotype and, if available, for the five paratypes (in parentheses) are given in micrometers $(\mu \mathrm{m})$. When it comes to leg chaetotaxy, the number of solenidia is given in parentheses.

\section{SYSTEMATICS}

Family Neopygmephoridae Cross, 1965

Genus Andrebochkovia gen.n.

Type species: Andrebochkovia cochlearis sp.n.

Diagnosis. Female. Body oval. Gnathosomal capsule of about equal length and width, dorsally with two pairs of cheliceral setae (cha, chb); postpalpal setae ( $p p$ ) present; palps short, with two pairs of dorsal setae ( $d F e, d G e)$. Palpal tibiotarsus completely covered by anterior part of femorogenu, small, with tiny tibial claw. Subcapitulum with one pair of setae $m$, alveolal pits $n$ absent; palps ventrally with accessory setigenous structure, palpal solenidion absent; cheliceral stylets unusually thick and strong, about half as long as gnathosomal capsule, cheliceral levers large and well sclerotized (Fig. 5A). Pharyngeal pumps tripartite situated closely to each other; pharyngeal pump 1 small, 
bow-shaped, striated, pharyngeal pump 2 very large and long, sausage-shaped and weakly striated laterally, pump 3 very small, smooth (Fig. 2B). Posterior margin of prodorsum slightly covered by anterior part of tergite C. Prodorsum with two pairs of simple setae $\left(v_{2}, s c_{2}\right)$, pair of clavate trichobothria $\left(s c_{1}\right)$ and small, round stigmata located anteriorly to setae $v_{2}$. Dorsal idiosomal setae not modified. Tergite $\mathrm{C}$ with two pairs of setae $\left(c_{1}, c_{2}\right)$; tergite $\mathrm{D}$ with one pair of setae $(d)$ and round cupules $i a$; tergite $\mathrm{EF}$ with two pairs of setae $(e, f)$; tergite $\mathrm{H}$ with two pairs of setae $\left(h_{1}, h_{2}\right)$ and round cupules $i h$. Coxal fields I with two pairs of setae $(1 a, 1 b)$; coxal fields II with two pairs of setae $(2 a, 2 b)$; coxal fields III with three pairs of setae $(3 a, 3 b$, $3 c)$; coxal fields IV with three pairs of setae $(4 a$, $4 b, 4 c)$. Pseudanal segment with three pairs of setae $\left(p s_{1-3}\right)$. Apodemes 1 (ap1) and 2 (ap2) well developed and joined with prosternal apodeme (appr), sejugal apodeme (apsej) well developed and joined with appr; apodemes 3 (ap3) very weak, divided into several parts, apodemes 4 (ap4) long, reaching distinctly beyond bases of setae $3 b$. Apodemes 5 absent. Secondary transverse apodeme absent. Posterior margin of posterior sternal plate entire. Anterior genital sclerite (ags) long, bell-like, posterior genital sclerite (pgs) U-shaped, shorter than ags, median genital sclerite (mgs) present. Ventral idiosomal setae not modified. Legs I and II subequal in length. Tibiotarsus I slightly thickened, with large claw, situated on short pretarsus; seta $d$ of femur I hook-like, seta $k$ long, pointed, seta-like; setae ( $t c$ ) situated on short pinnaculum. Claws on tarsus IV simple, claws on tarsi II and III thickened medially. Tarsus IV not strongly elongate; empodia on tarsi II-IV relatively short and wide. Solenidion on tibia IV absent. Femora III-IV divided into basi- and telofemur. Leg setation: leg I: $\operatorname{Tr} 1$ ( $\left.v^{\prime}\right), \mathrm{Fe} 3$ (d, l', $\left.v^{\prime \prime}\right), \mathrm{Ge} 4\left(l^{\prime}, l^{\prime \prime}, v^{\prime}, v^{\prime \prime}\right)$, TiTa 16(4) (d, l', l', v', v', $k,, t c^{\prime}, t c^{\prime \prime}, p$ ", $f t^{\prime}, f t^{\prime \prime}, p v^{\prime}$, $\left.p v ", p l ', p l ", s, \omega_{1}, \omega_{2}, \varphi_{1}, \varphi_{2}\right)$; leg II: Tr $1\left(v^{\prime}\right), \mathrm{Fe}$ 3 (d, l', v'), Ge 3 (l', l', v'), Ti 4(1) (d, l', v', v', $\varphi$ ), Ta 6(1) (tc', $t c ", p l$ ", $\left.p v^{\prime}, p v^{\prime \prime}, u^{\prime}, \omega\right)$; leg III: $\operatorname{Tr} 1\left(v^{\prime}\right), \operatorname{Fe} 2\left(d, v^{\prime}\right), \operatorname{Ge} 2\left(l^{\prime}, v^{\prime}\right), \operatorname{Ti} 4(1)\left(d, l^{\prime}\right.$, $\left.v^{\prime}, v^{\prime \prime}, \varphi\right)$, Та 6 ( $\left.t c^{\prime}, t c^{\prime \prime}, p l^{\prime \prime}, p v^{\prime}, p v^{\prime \prime}, u^{\prime}\right)$; leg IV: $\operatorname{Tr} 1\left(v^{\prime}\right), \operatorname{Fe} 2\left(d, v^{\prime}\right), \operatorname{Ge} 1\left(v^{\prime}\right), \operatorname{Ti} 4\left(d, l^{\prime}, v^{\prime}, v^{\prime \prime}\right)$, Ta 6 (tc', tc', $p l^{\prime \prime}, u$ ', $\left.p v^{\prime}, p v^{\prime \prime}\right)$.

Male and larva unknown.

Differential diagnosis. Among the genera with median genital sclerite, the new genus is most similar to Pseudopygmephorus Cross, 1965 in general appearance and in the shape of genital sclerites (see Khaustov and Trach 2014). The new genus could be distinguished from Pseudopygmephorus by: an erect solenidion $\omega_{1}$ (solenidion $\omega_{1}$ fused with tibiotarsus in Pseudopygmephorus); very strong and well sclerotized cheliceral stylets and levers (cheliceral stylets and levers are very small and difficult to discern in Pseudopygmephorus); a very long, sausage-shaped pharyngeal pump 2 (pharyngeal pump 2 is usually small and oval in Pseudopygmephorus); and the absence of a palpal solenidion (palpal solenidion is present in Pseudopygmephorus).

Species included. The genus Andrebochkovia includes two species: $A$. cochlearis sp.n. and $A$. madagascariensis sp.n.

Distribution and habitats. Andrebochkovia cochlearis sp.n. is phoretic on beetles Apogonia destructor (Scarabaeidae: Melolontinae) in Indonesia; A. madagascariensis sp.n. is phoretic on beetles Adoretus cf. vittatus (Scarabaeidae: Rutelinae) in Madagascar.

Etymology. The genus is named in memory of a prominent Russian acarologist Andrei Bochkov.

\section{Andrebochkovia cochlearis sp. n.}

(Figs. 1-6)

Description. Female (Figs. 1-6). Length of idiosoma 220 (215-230), width 130 (125-135).

Idiosomal dorsum (Figs. 1A, 6A, B). All dorsal shields with numerous small dimples. All dorsal setae barbed. Setae $s c_{2}$ and $c_{2}$, pointed, other dorsal setae blunt-ended. Trichobothria with short stem, clavate, sparsely barbed, with rounded apex. Posterior margins of tergites $\mathrm{C}$ and $\mathrm{D}$ weakly concave. Lengths of dorsal setae: $v_{2} 17$ (17-19), $s c_{2} 45$ (44-47), c 34 (33-35), $c_{2} 46$ (42-47), d38 (36-39), e 25 (21-25), $f 41$ (40-42), $h_{1} 52$ (47-52), $h_{2} 27$ (23-27). Distances between setae: $v_{2}-v_{2} 31$ (30-32), $s c_{2}-s c_{2} 36$ (35-38), $c_{1}-c_{1} 48$ (46-50), $c_{1}-c_{2} 28$ (26-29), $d-d 36$ (35-36), e-f6 (6-7), f-f 32 (3234), $h_{1}-h_{1} 15$ (13-15), $h_{1}-h_{2} 15$ (14-17).

Idiosomal venter (Figs. 1B, 6C, D). Ventral plates with numerous small dimples. All ventral setae pointed. Setae of posterior sternal plate smooth, other ventral setae barbed; setae $1 b$ and $2 a$ strongly barbed. Posterior margins of posterior sternal and aggenital plates straight. Lengths of ventral setae: $1 a 27$ (27-31), 1 b 27 (24-28), $2 a 34$ (33-35), $2 b 26$ (24-30), $3 a 20$ (19-20), $3 b 22$ (20-22), 3c 20 (2022), $4 a 19$ (19-21), $4 b 28$ (28-32), 4c 24 (23-25), $p s_{1} 20$ (19-21), $p s_{2} 14$ (12-15), $p s_{3} 18$ (17-18). 


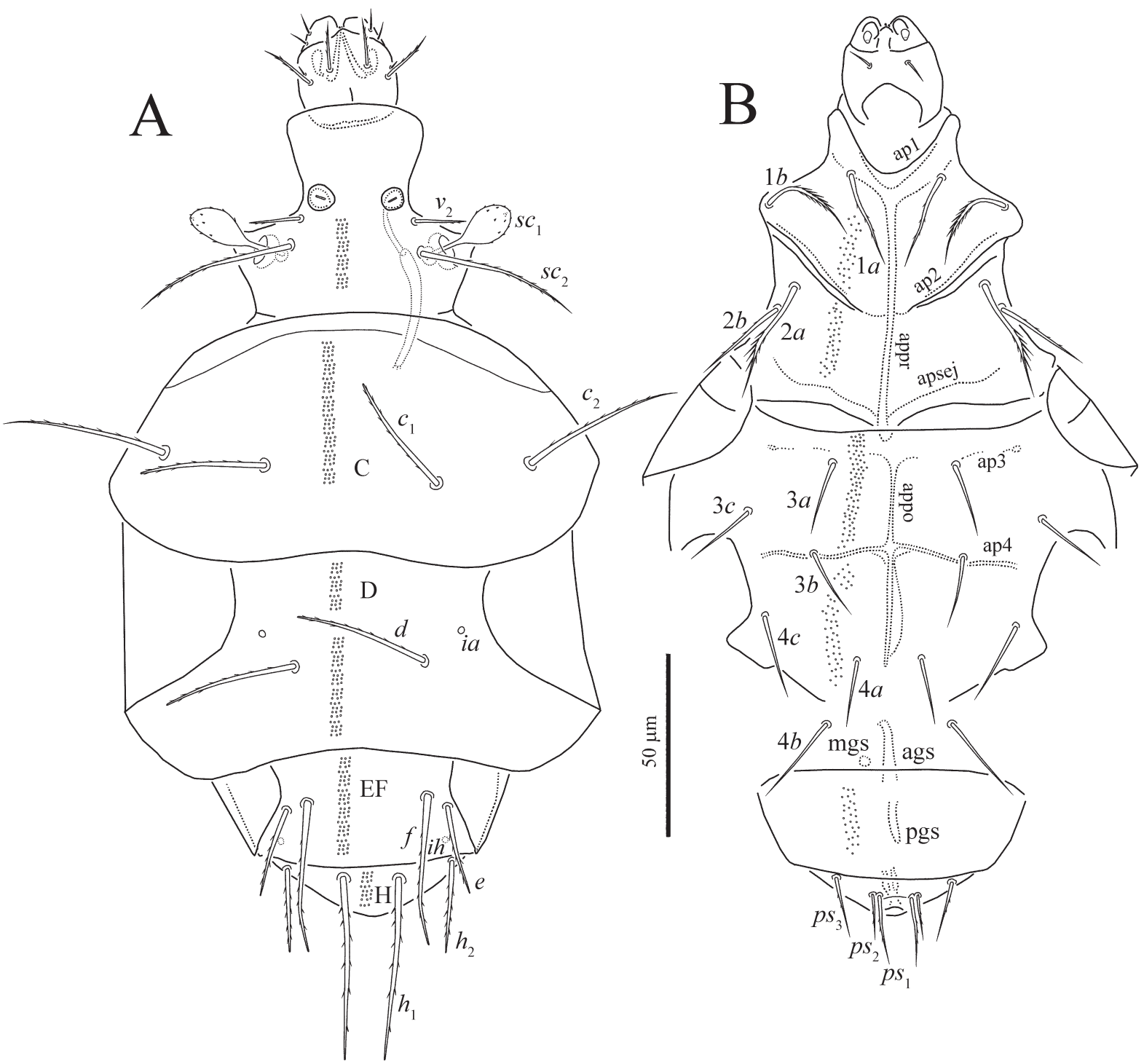

Fig. 1. Andrebochkovia cochlearis sp.n., female: A-dorsum of the body, B-venter of the body. Legs omitted.

Gnathosoma (Figs. 2, 5, 6D). Gnathosoma almost oval in outline. Length of gnathosoma 29 (28-30), width 26 (26-27). Dorsal median apodeme well developed. Cheliceral setae cha 15 (15-17) and chb 15 (15-18) distinctly barbed and pointed; postpalpal setae $(p p)$ short, needle-like, situated anterolaterally to bases of $c h a$. Setae $d F e$ and $d G e$ subequal, smooth and pointed; subcapitular setae $m 7$ (6-7) smooth and pointed.

Legs (Figs. 3, 4, 6B, E, F). Leg I (Figs. 3A, 6E). Lengths of solenidia $\omega_{1} 8(7-8), \omega_{2} 15(15-16), \varphi_{1}$ 13 (13), $\varphi_{2} 7$ (7); $\varphi_{1}$ digitiform, $\omega_{1}$ short and wide, semi-oval, $\omega_{2}$ and $\varphi_{2}$ baculiform; $\omega_{2}$ slightly curved. Seta $l$ ' of femur spoon-like, smooth, blunt-ended (Fig. 6B); other leg setae (except eupathidia $(f t)$, (tc), $p$ " and hook-like seta $d$ of femur) barbed and pointed. Leg II (Figs. 3B, 6F). Solenidion $\omega 10$ (10-11) digitiform; solenidion $\varphi 4$ (4) weakly clavate, situated in depression (Fig. 6F). All leg setae barbed; seta $d$ of femur blunt-ended; other leg setae pointed. Leg III (Fig. 4A). Solenidion $\varphi 4$ (4) weakly clavate, situated in depression. All leg setae barbed. Seta $d$ of femur and $u$ ' of tarsus bluntended; other leg setae pointed. Leg IV (Fig. 4B). All leg setae barbed. Setae $d$ of femur, $v$ ' of genu, and $v$ " of tibia blunt-ended; other leg setae pointed.

Differential diagnosis. Andrebochrovia cochlearis differs from $A$. madagascariensis by: spoon-shaped seta $l$ ' of femur I (seta $l$ 'of femur I is not modified in A. madagascariemsis); pointed 

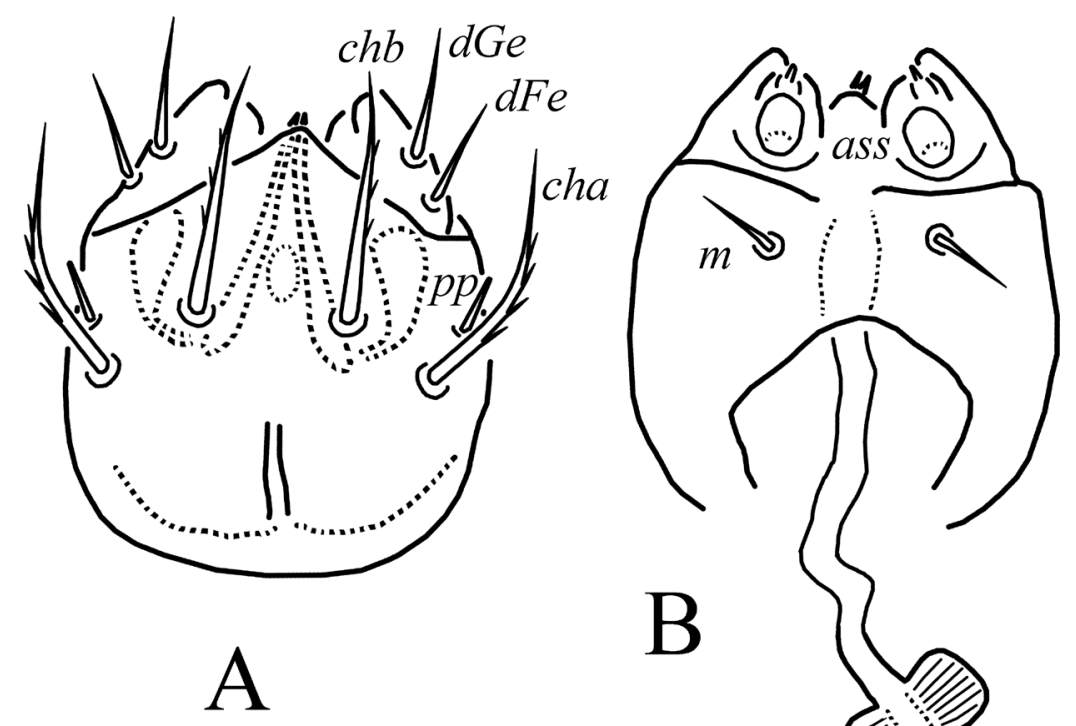

$\mathrm{B}$

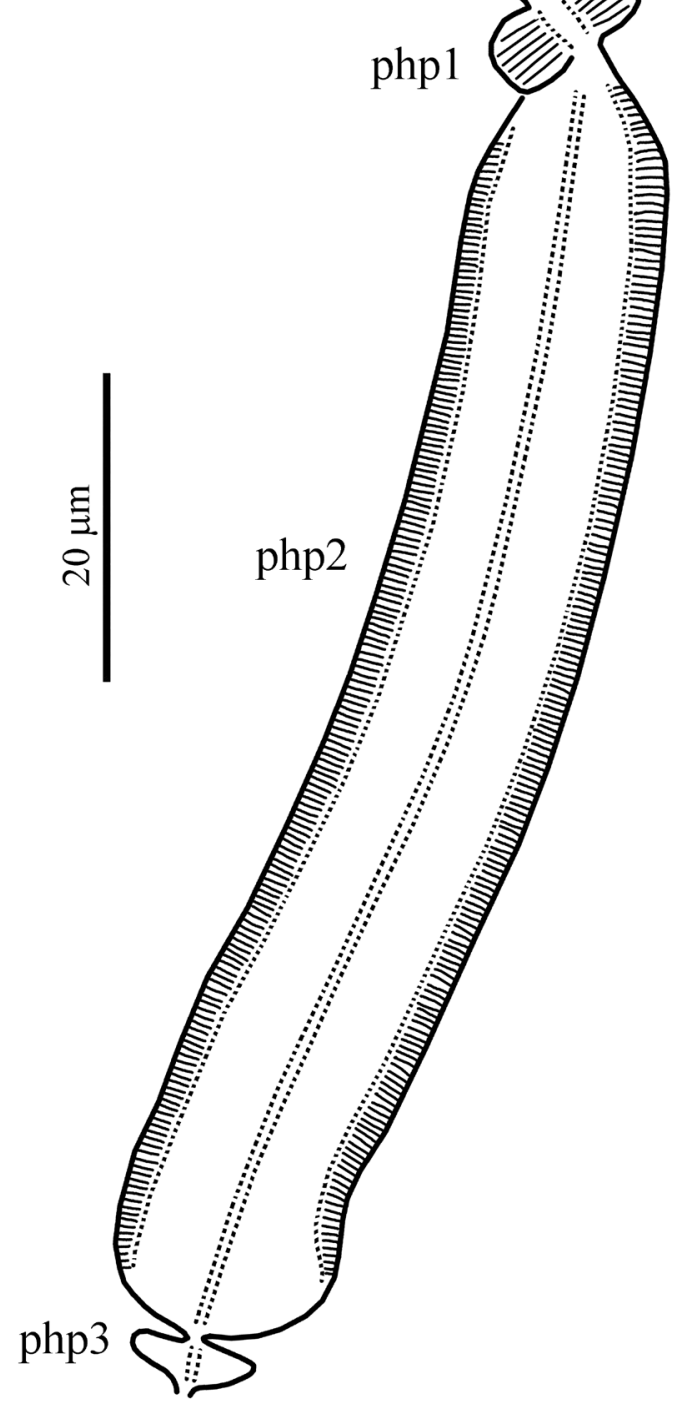

Fig. 2. Andrebochkovia cochlearis sp.n., female: A—gnathosoma in dorsal view, B-gnathosoma and pharyngeal pumps in ventral view. 


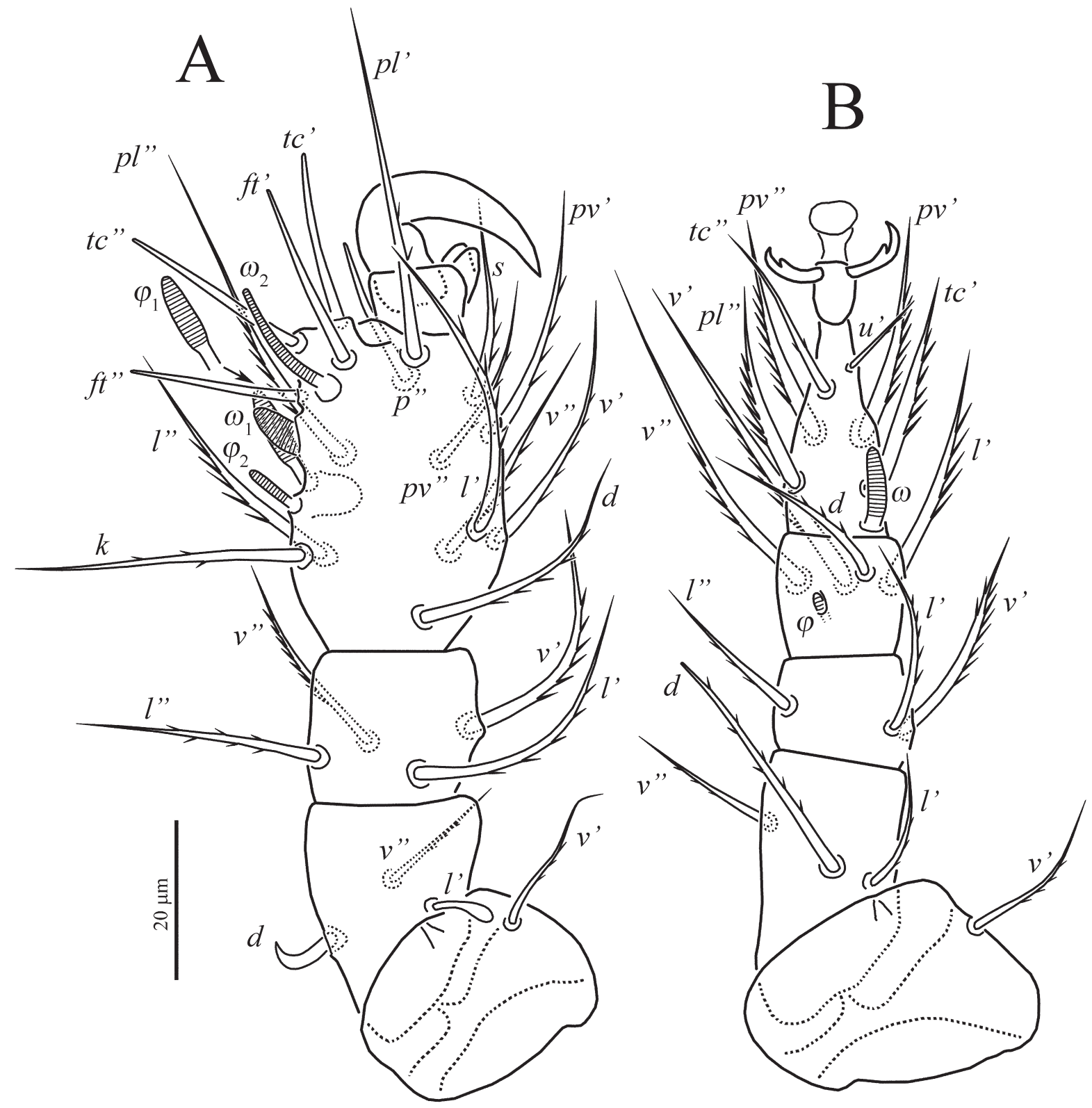

Fig. 3. Andrebochkovia cochlearis sp. n., female: A-left leg I in dorsal view, B-left leg II in dorsal view.

setae $s c_{2}$ and $c_{2}$ (setae $s c_{2}$ and $c_{2}$ are blunt-ended in A. madagascariensis); and pointed seta $v$ ' of trochanter IV (seta $v$ ' of trochanter IV is blunt-ended in A. madagascariensis).

Type material. Female holotype, slide ZISP T-Neop-002, on the beetle Apogonia destructor: Indonesia, Rinca Island, 12.VII.1962, L.Darevskyi leg.; paratypes: 4 females, same data; 59 females on the beetle Apogonia destructor: Indonesia, Java, Bogor, 11.VII.1960, S. Khrushchev leg.

Type deposition. The holotype and four paratypes are deposited in the collection of Zoological Institute of RAS, Saint Petersburg, Russia; other paratypes are deposited in the collection of the Tyumen State University Museum of Zoology, Tyumen, Russia.

Etymology. The name of the new species is derived from Latin cochlearis, meaning spoon and refers to the unusual spoon-shaped seta $l$ ' on femur I.

\section{Andrebochkovia madagascariensis sp. $\mathrm{n}$.}

(Figs. 7-9)

Description. Female (Figs. 7-9). Length of idiosoma 240, width 120. 


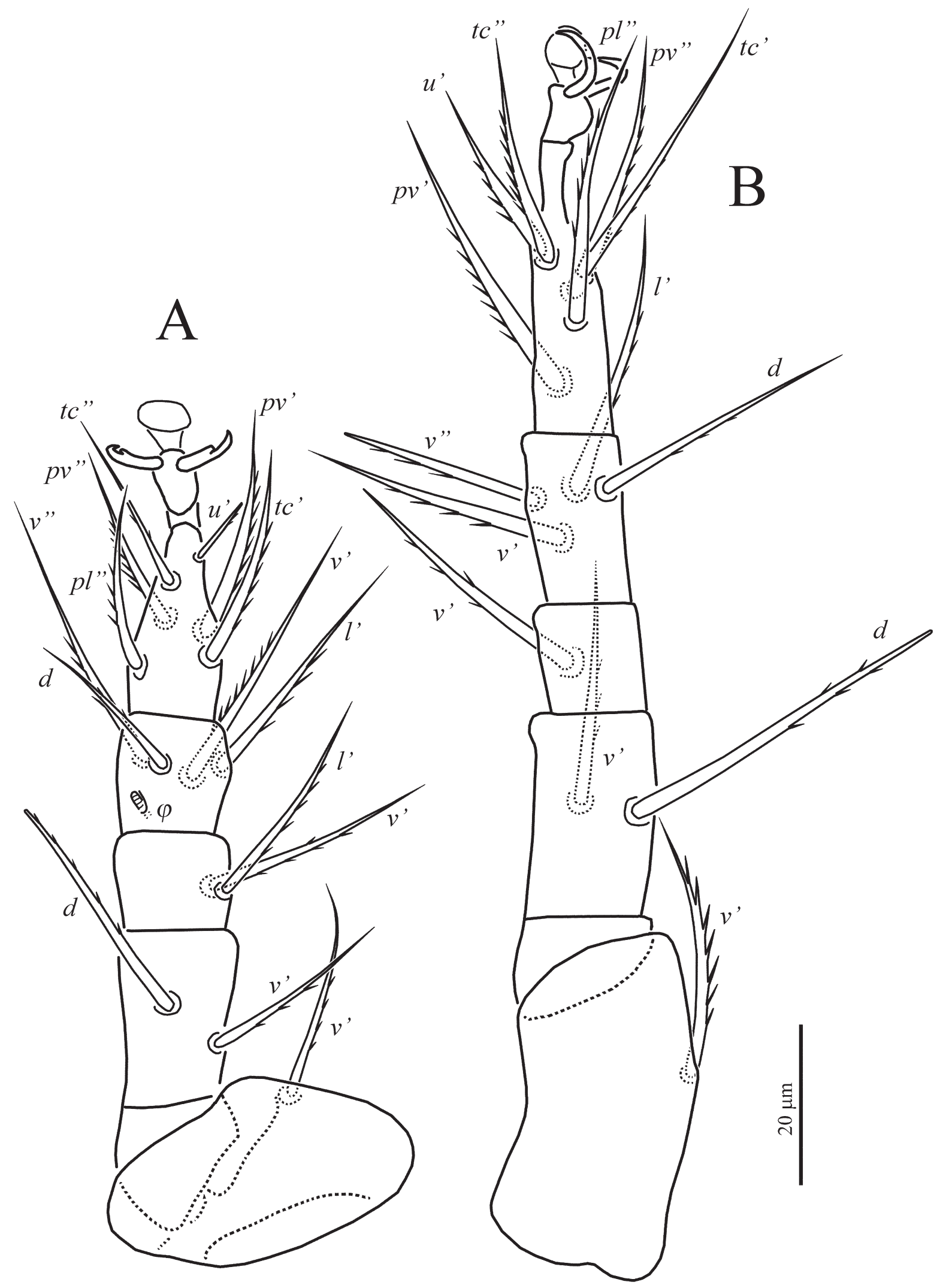

Fig. 4. Andrebochkovia cochlearis sp. n., female: A—left leg III in dorsal view, B-left leg IV in dorsal view. 


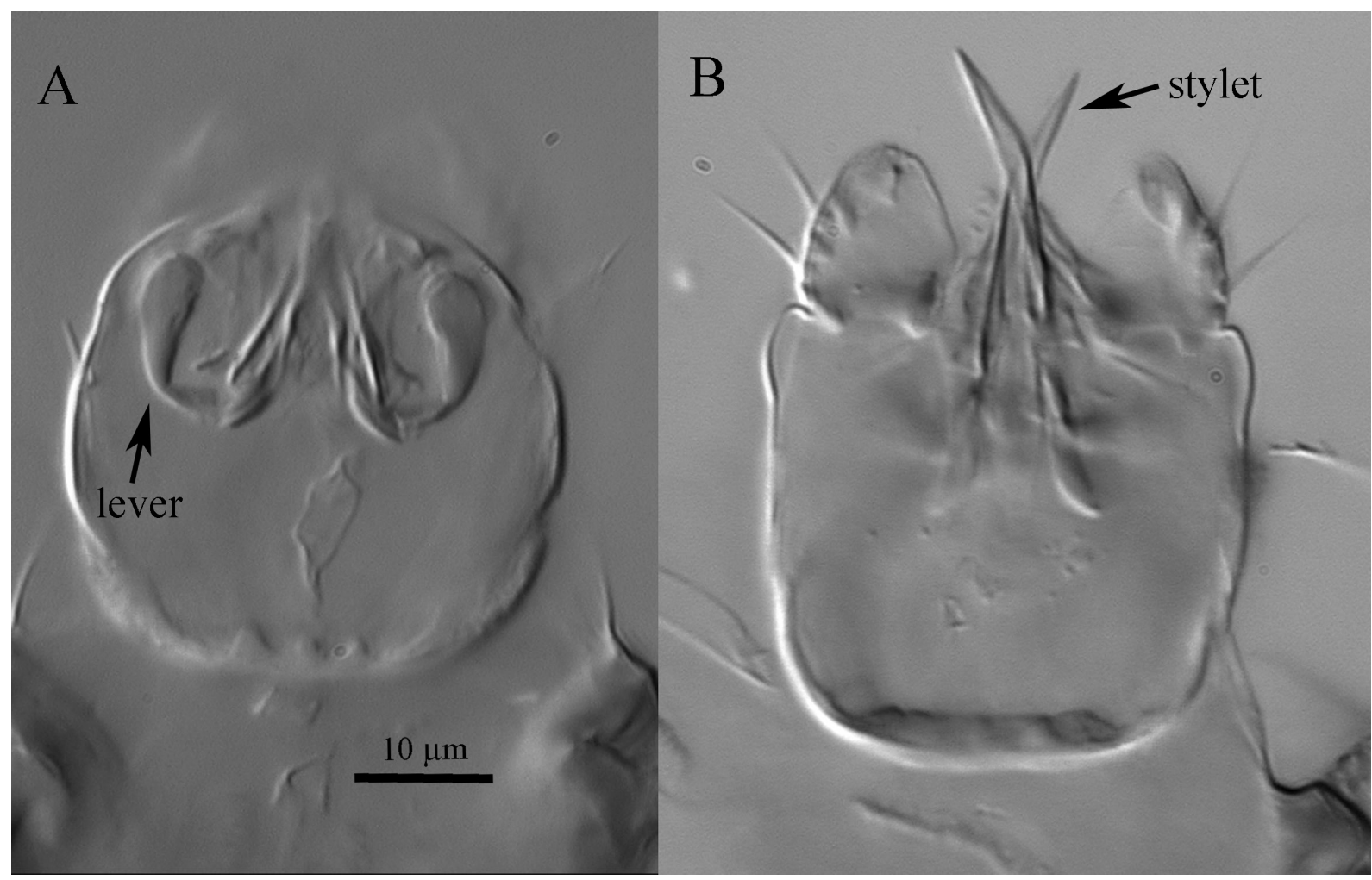

Fig. 5. DIC micrographs of Andrebochkovia cochlearis sp.n., female: A-gnathosoma with focus on cheliceral levers, $\mathrm{B}$ - gnathosoma with focus on cheliceral stylets.

Idiosomal dorsum (Fig. 7A). All dorsal shields with numerous small dimples. All dorsal setae barbed and blunt-ended. Trichobothria with short stem, clavate, sparsely barbed, with rounded apex. Posterior margins of tergites $\mathrm{C}$ and $\mathrm{D}$ almost straight. Lengths of dorsal setae: $v_{2} 15, s c_{2} 35, c_{1}$ 27, $c_{2} 33, d 30, e$ 21, $f 34, h_{1} 40, h_{2} 22$. Distances between setae: $v_{2}-v_{2} 30, s c_{2}-s c_{2} 32, c_{1}-c_{1} 47, c_{1}-$ $c_{2} 25, d-d 39, e-f 8, f-f 35, h_{1}-h_{1} 18, h_{1}-h_{2} 15$.

Idiosomal venter (Fig. 7B). Ventral plates with numerous small dimples. All ventral setae pointed. Setae of posterior sternal plate and $p s_{2}$ smooth, other ventral setae barbed; setae $1 b$ and $2 a$ strongly barbed. Other characters as in A. cochlearis. Lengths of ventral setae: $1 a 26,1 b 25,2 a 31,2 b$ $29,3 a 20,3 b 24,3 c 20,4 a 19,4 b 34,4 c 23, p s_{1} 21$, $p s_{2} 12, p s_{3} 18$.

Gnathosoma. In general, very similar to that of A. cochlearis. Setae cha 12, chb 17.

Legs (Figs. 8, 9). Leg I (Fig. 8A). In general, as in $A$. cochlearis, except the following: seta $l$ ' of femur not modified, smooth and pointed; lengths of solenidia $\omega_{1} 11, \omega_{2} 13, \varphi_{1} 13, \varphi_{2}$ 7. Leg II (Fig. $8 \mathrm{~B})$ as in A. cochlearis. Solenidia $\omega 12, \varphi 5$. Leg
III (Fig. 9A) as in A. cochlearis. Leg IV (Fig. 9B). All leg setae barbed. Setae $v$ ' of trochanter, $d$ of femur, and $v$ " of tibia blunt-ended; other leg setae pointed.

Differential diagnosis. See diagnosis for $A$. $\mathrm{CO}$ chlearis.

Type material. Female holotype, slide ZISP T-Neop-003, on the beetle Adoretus cf. vittatus Brenske (Scarabaeidae, Rutelinae), Madagascar, 6.I.2001, D. Suarez leg.

Type deposition. The holotype is deposited in the collection of Zoological Institute of RAS, Saint Petersburg, Russia.

Etymology. The name of the new species refers to its distribution in Madagascar.

\section{ACKNOWLEDGEMENTS}

Authors thank A.N. Bobylev (Tyumen State University, Tyumen, Russia) for SEM micrographs. The study was supported by the Russian Foundation for Basic Research (RFBR) research project No. 18-04-01092A. The junior author's portion of the study was performed in the framework of the state research project AAAA-A19-119020690101-6. 


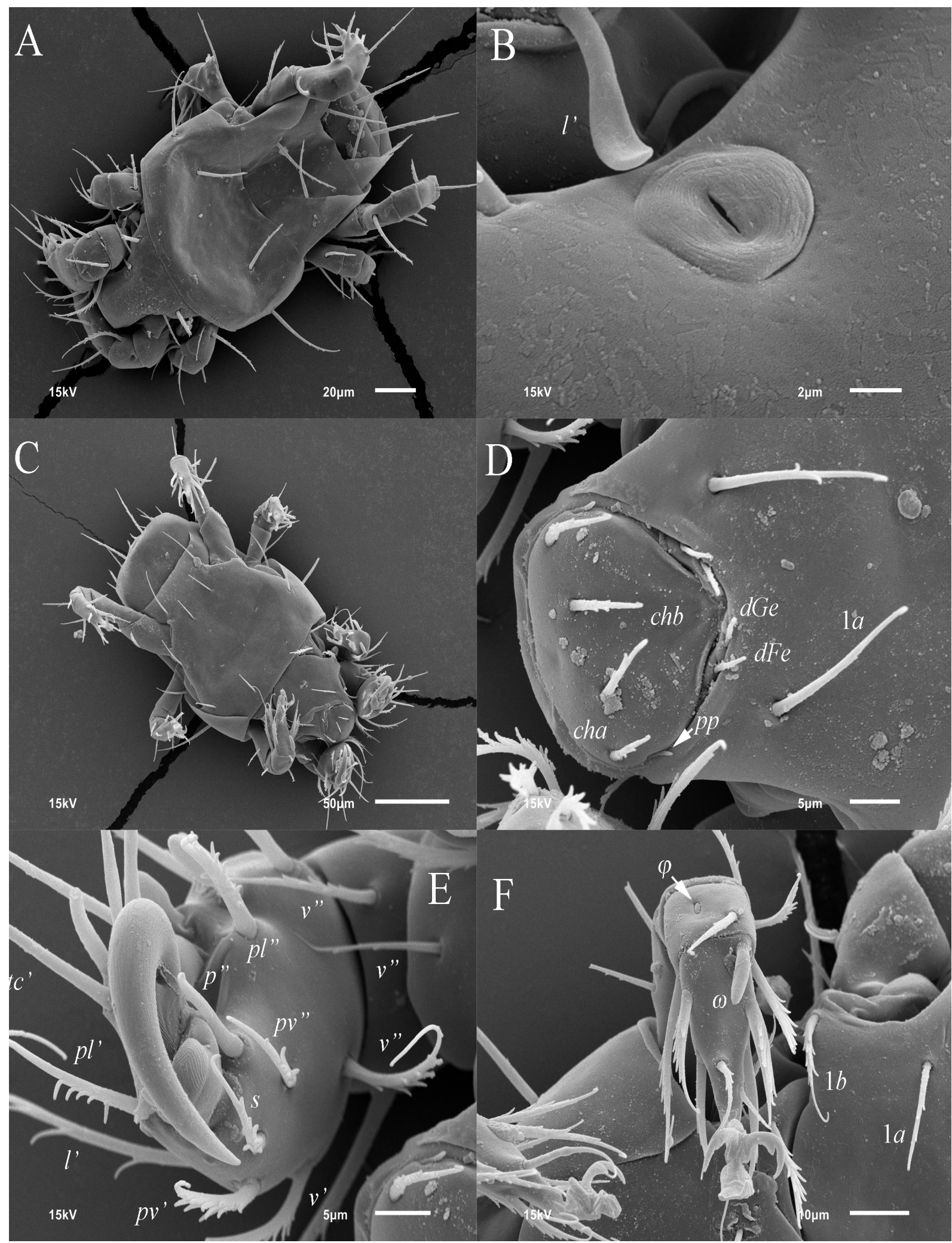

Fig. 6. SEM micrographs of Andrebochkovia cochlearis sp.n., female: A-general view dorsally, B-stigma and modified seta $l$ ' of femur I, C-general view ventrally, D-hypognathous gnathosoma and anterior part of anterior sternal plate, E-tibiotarsus I in frontal view, F-tibia and tarsus II in dorsal view. 

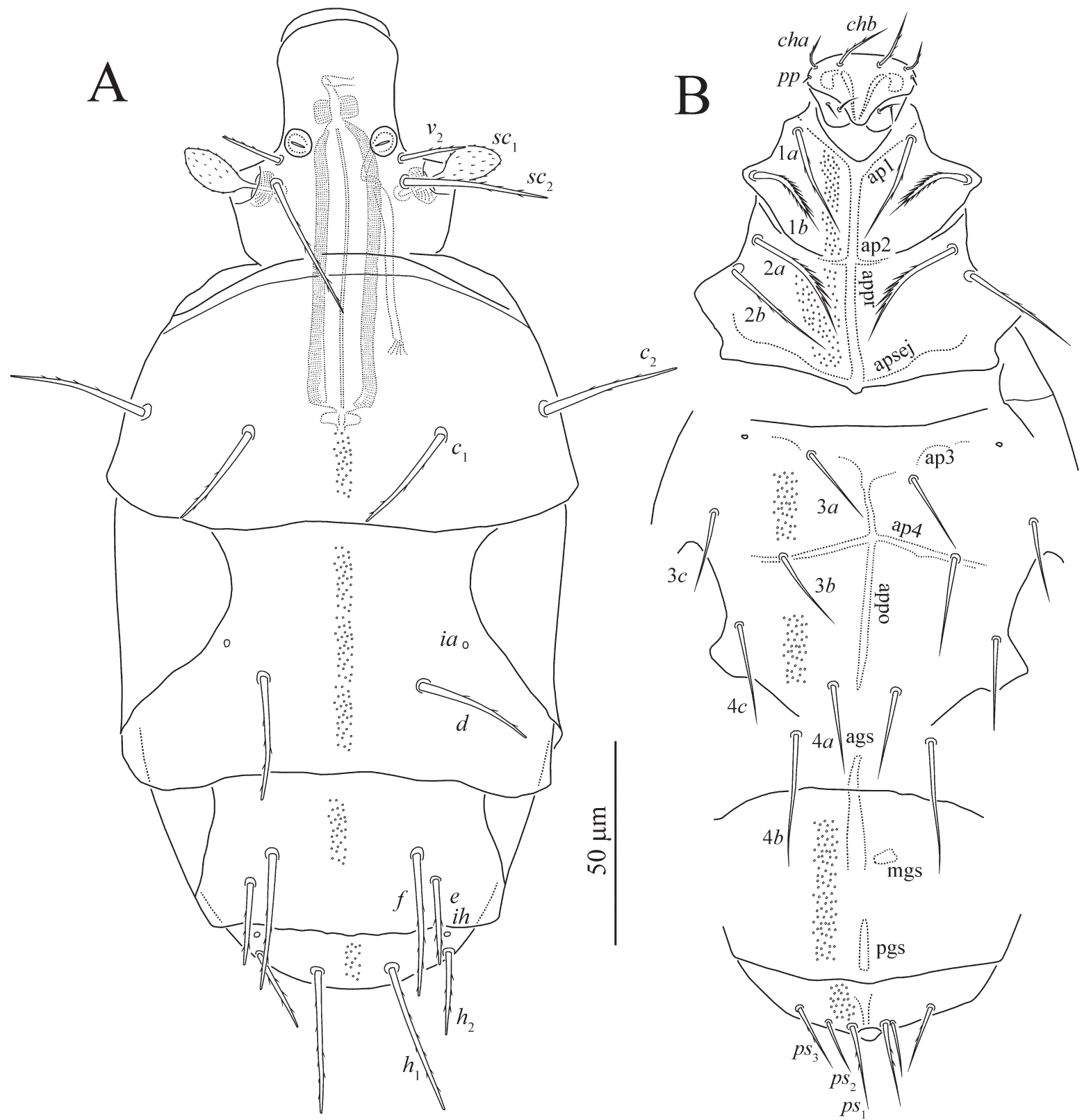

Fig. 7. Andrebochkovia madagascariensis sp.n., female: A-dorsum of the body, B — venter of the body. Legs omitted.

\section{REFERENCES}

Grandjean, F. 1944. Observations sur les Acariens de la famille des Stigmaeidae. Archives des Sciences Physiques et Naturelles, 26: 103-131.

Grandjean, F. 1947. L'origine pileuse des mors et la chaetotaxie de la mandibule chez les Acariens actinochitineux. Comptes rendus des Séances de l'Academie des Sciences, 224: 1251-1254.

Khaustov, A.A. 2004. Mites of the family Neopygmephoridae Cross, 1965 stat.n. and their position in Heterostigmata. In: Y.S. Balashov (Ed.). Proceed- ings of VIII Russian Acarological Conference, St.-Petersburg. Zoological Institute of RAS, St.Petersburg, 137 pp. [In Russian]

Khaustov, A.A. 2008. Mites of the family Scutacaridae of Eastern Palaearctic. Akademperiodyka, Kiev, 291 pp.

Khaustov, A.A. 2010. A new species of mites of the genus Pseudopygmephorus (Acari: Heterostigmata: Neopygmephoridae) associated with Aphodius fimetarius (Coleoptera: Scarabaeidae) from Crimea. Acarina, 18: 261-264. 

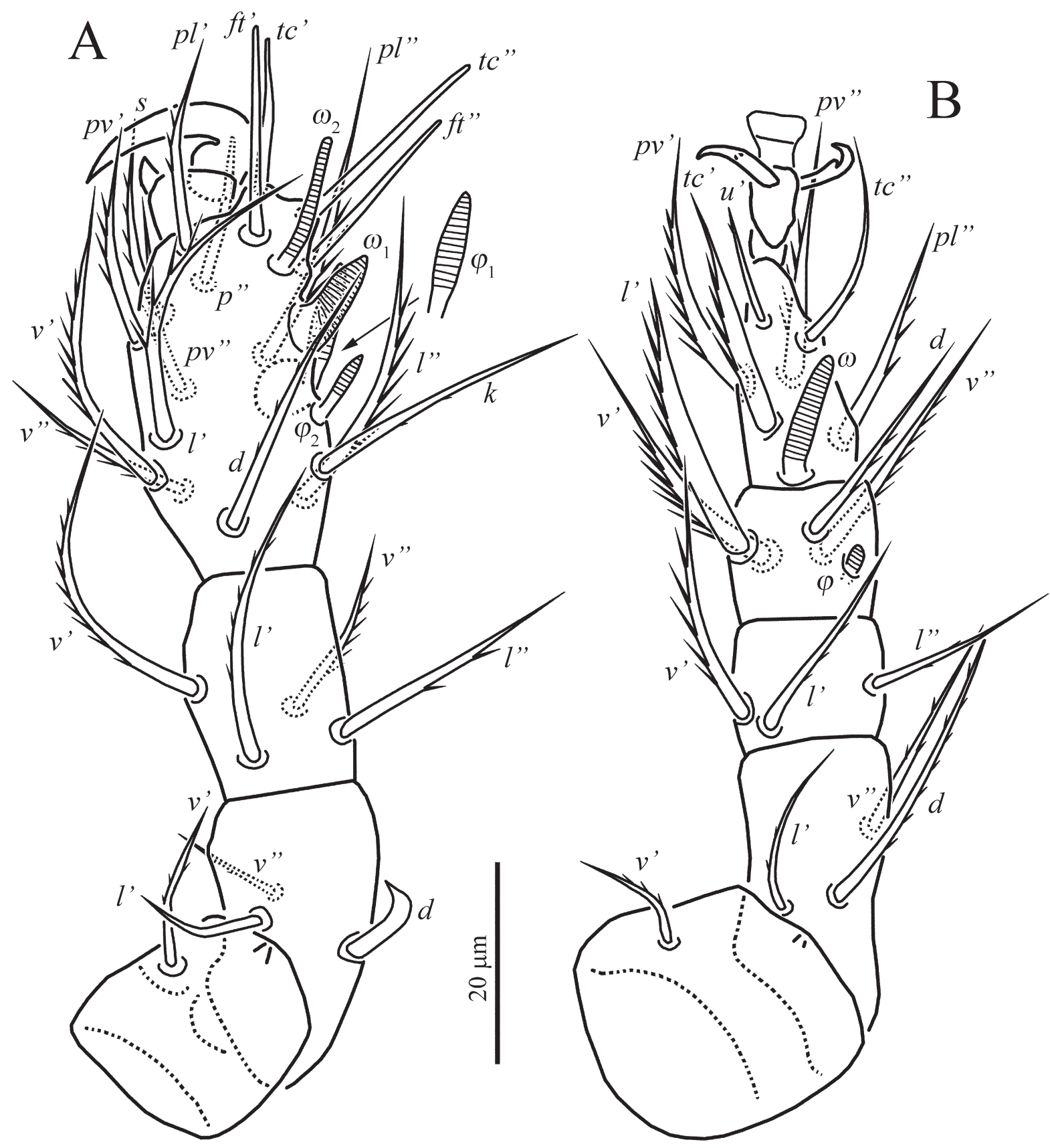

Fig. 8. Andrebochkovia madagascariensis sp.n., female: A—right leg I in dorsal view, B —right leg II in dorsal view.

Khaustov, A.A. and Frolov, A.V. 2018a. New taxa of pygmephoroid mites (Acari: Pygmephoroidea: Pygmephoridae, Neopygmephoridae) phoretic on Enoplotrupes sharpi (Coleoptera: Geotrupidae) from Thailand. Zootaxa, 4442 (2): 277-292.

Khaustov, A.A. and Frolov, A.V. 2018b. A new species, new genus and new records of heterostigmatic mites (Acari: Heterostigmata) phoretic on scarab beetles of the subfamily Orphninae (Coleoptera: Scarabaeidae). Zootaxa, 4514 (2): 181-201.
Khaustov, A.A. and Mandelshtam, M.Y. 2017. Coleopygmephorus gen. nov., a new genus of the family Neopygmephoridae (Acari: Pygmephoroidea) with redescription of C. loricophilus (Sevastianov 1981) comb. nov. and description of a new species associated with bark beetles (Coleoptera: Curculionidae: Scolytinae) from Far East of Russia. International Journal of Acarology, 43: 30-38.

Khaustov, A.A. and Minor, M.A. 2018. New taxa of the mite family Neopygmephoridae (Acari: Heter- 


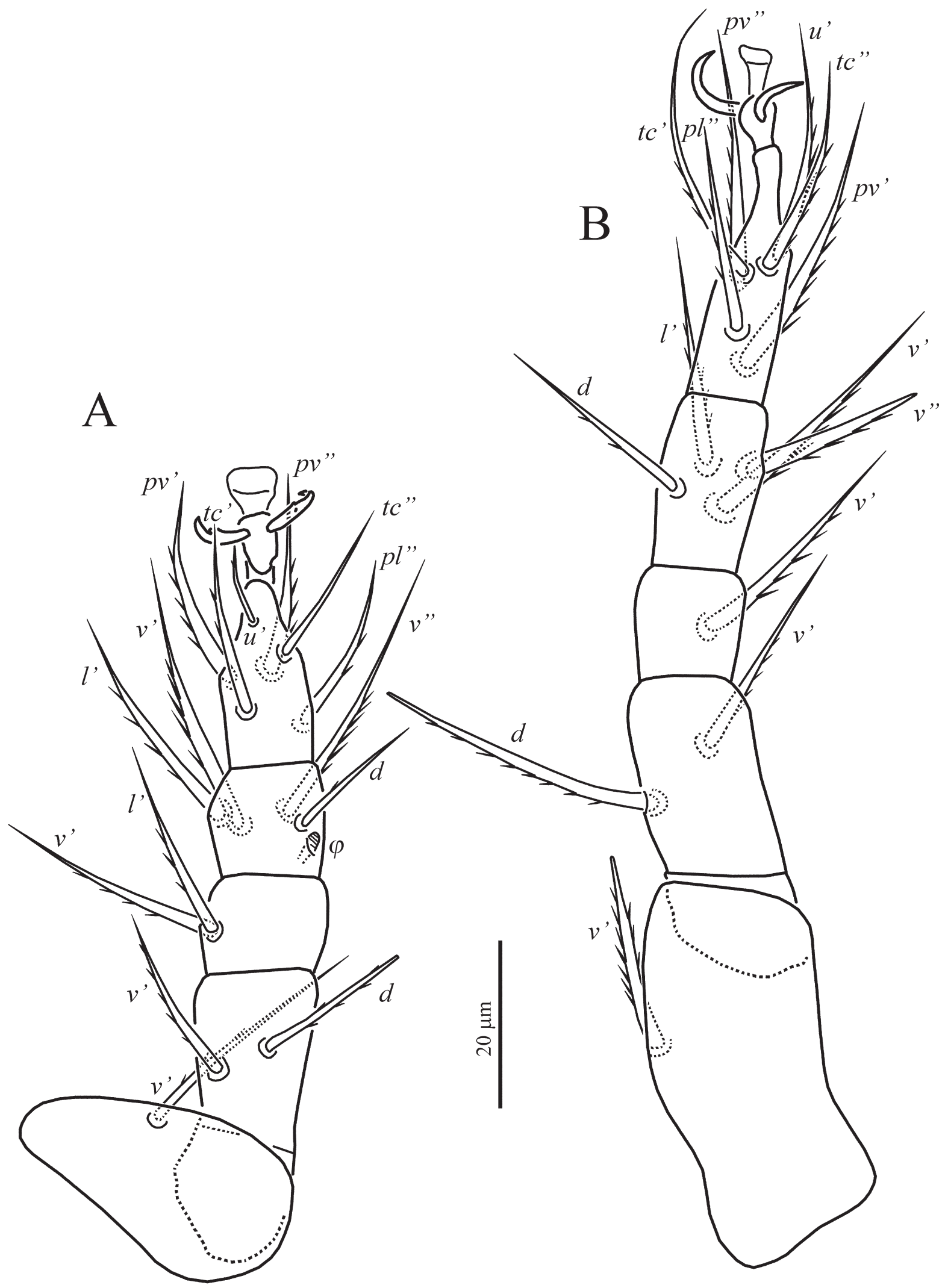

Fig. 9. Andrebochkovia madagascariensis sp.n., female: A—right leg III in dorsal view, B—right leg IV in dorsal view. 


\section{A.A. Khaustov and A.V. Frolov}

ostigmata) from alpine New Zealand. Zootaxa, 4415 (2): 276-296.

Khaustov, A.A. and OConnor, B.M. 2019. Three new species of Rhinopygmephorus (Acari: Heterostigmata: Neopygmephoridae) associated with halictid bees (Hymenoptera: Halictidae). International Journal of Acarology. DOI: 10.1080/01647954.2019.1668478

Khaustov, A.A. and Sazhnev, A.S. 2016. Mites of the families Neopygmephoridae and Scutacaridae associated with variegated mud-loving beetles (Coleoptera: Heteroceridae) from Russia and Kazakhstan. Zootaxa, 4175 (3): 261-273.

Khaustov, A.A. and Trach, V.A. 2012. A new genus and species of the family Neopygmephoridae (Acari: Heterostigmata: Pygmephoroidea) associated with Geotrupes spiniger (Coleoptera: Geotrupidae) from Ukraine. Acarina, 20: 3-7.

Khaustov, A.A. and Trach, V.A. 2014. Mites of the superfamily Pygmephoroidea (Acari: Heterostigmata: Neopygmephoridae, Pygmephoridae) associated with Trox cadaverinus (Coleoptera:
Trogidae) from the Far East of Russia, with description of a new genus and two new species. Zootaxa, 3754: 86-96.

Lindquist, E.E. 1986. The world genera of Tarsonemidae (Acari: Heterostigmata): a morphological, phylogenetic, and systematic revision, with a reclassification of family-group taxa in the Heterostigmata. Memoirs of Entomological Society of Canada, 118: 1-517.

Sobhi, M., Hajiqanbar, H. and Mortazavi, A. 2017. New species and records of heterostigmatic mites (Acari: Prostigmata: Heterostigmata) phoretic on scarabaeid dung beetles (Coleoptera: Scarabaeidae) from northwestern Iran. Zootaxa, 4276: 427-434.

Zhang, Z., Fan, Q.H., Pesic, V., Smit, H., Bochkov, A.V., Khaustov, A.A., Baker ,A., Wohltmann, A., Wen, T., Amrine, J.W. et al. 2011. Order Trombidiformes Reuter, 1909. In: Z.-Q. Zhang (Ed.). Animal biodiversity: an outline of higher-level classification and survey of taxonomic richness. Zootaxa, 3148: 129-138. 